\title{
ROLE-PLAYING METHOD IN DEVELOPING ISLAMIC STUDENT'S ENTREPRENEURSHIP MENTALITY
}

\author{
Nur Rizqi Febriandika*, Sisna Gaida \\ Universitas Muhammadiyah Surakarta, Indonesia \\ Institut Agama Islam Negeri (IAIN) Kudus, Indonesia \\ rizqi.febriandika@ums.ac.id, ghaidasisna@gmail.com \\ https://doi.org/10.46367/iqtishaduna.v10i1.319
}

Received: Apr 17, 2021 Revised: May 06, 2021 Accepted: May 24, 2021 Published: Jun 29, 2021

\begin{abstract}
The purpose of this study is to determine the application of the role-playing method as well as supporting and inhibiting factors in fostering the entrepreneurial mentality of students in the "Theme of My Living Area" The subtheme of "My Living Environment" in 2013 curriculum Class IV at Madrasah Ibtidaiyah (MI) Muhammadiyah 2 Kudus Special Program. This research is a type of field research using a qualitative descriptive approach. Interviews, observation, and documentation are used as data collection technique. This study indicates that thematic learning at MI Muhammadiyah 2 Kudus has been running according to the stages in thematic learning, namely the planning stage, the implementation stage, and the evaluation stage. There are three stages in role-playing, namely: preparation, implementation, evaluation. Some student act as mango farmers, fruit juice sellers, bookstore owners, employees, barber services, buyers. The use of a lot of time inhibiting factor is a lot of time.
\end{abstract}

Keywords: Thematic Learning, Role-Playing Method, Entrepreneurship Mentality.

\section{INTRODUCTION}

Education can develop the abilities of students both in the cognitive, affective, psychomotor domains, as well as improving the quality of human life. The main activity in education in schools is teaching and learning (Luo 2019). Students learn at school to broaden their knowledge of knowledge, form a commendable attitude and are skilled in solving a problem. The teacher's task in the learning process is to create a creative, innovative learning atmosphere, and later the lessons will benefit students and can be applied in everyday life (Xu 2018).

The learning method has an important position in order to achieve the objectives of the learning process. The learning method is defined as the method used by the teacher in carrying out its functions and is a tool to achieve learning objectives. The learning method is more procedural. In selecting the teaching method, the teacher must be careful and adjust to the material to be delivered in order to create an effective and efficient learning process (Erbil and Kocabaş 2018). 
The learning method plays an important role in a series of learning systems, for that we need teacher intelligence and proficiency in choosing learning methods. In order for the learning objectives boths cognitive, affective and psychomotor to be achieved, the learning method is directed to achieve these goals, namely emphasizing more on process learning. Professional teachers must have extensive knowledge regarding the field of study to be taught, have theoretical concepts, be able to choose the right models, strategies and methods and be able to apply them in learning activities, develop creative subject matter (Fedosejeva et al. 2018).

One of the learning methods that involve students actively, so that the learning process is carried out and can motivate students to perform their best is the role-playing method (Guerrero et al. 2020). The role-playing method is a learning method in which it shows the visible behavior of students or imitating situations from historical figures in such a way or community behavior, for example how to inspire people to maintain environmental health, maintain greening/forests, village security, evoke the spirit of entrepreneurship and cooperatives, and so on.

Through the role-playing method, students try to explore the relationships between humans by demonstrating and discussing them, so that together students can explore feelings, attitudes, values, and various problem solving strategies. At the time of implementing the role-playing method, it is expected to be able to provide direct experience to students regarding the material being studied so that later it can be applied in everyday life (Nurdin et al. 2018).

The importances of building the entrepreneurial mentality of students since children are still in elementary school. Why in elementary schools (SD)? Because education in elementary schools is a basic education level that serves as layings of scientific basics and helps optimize children's development through teacher-guided learning (Wijayanti 2017). It is better if it fosters the entrepreneurial mentality of students from elementary school to college. If they are trained from a young age, their entrepreneurial mentality will be stronger so that when they graduate, they can open jobs for the community.

Some educational institutions only produce skilled students but do not have an entrepreneurial mentality. So that, in the end students are formed as workers who are ready to work, not job creators. Long before there was a process of nurturing an entrepreneurial mindset through schooling, there was a process of establishing an entrepreneurial mindset, namely through a process of learning and self-habituation as a trigger for a future character (Bystrova et al. 2017). Developed nations are supported by related human resources. So that it has advantages in all fields.

Naturally, the role-playing method motivates children to know something more deeply, and children spontaneously develop their abilities. Through this method, children stimulate the senses, learn to use their muscles, coordinate vision and movement, gain mastery of the body, and acquire new skills (Pujiati 2015).

The role playing method is better than conventional learning methods in general. This method can explore human relationships by demonstrating and discussing them so that together we can explore feelings, attitudes, values, and various problem solving strategies. Early childhood education is often faced with 
various problems, either through the field of development or through social relations.

Also as an outcome, the role-playing method was applied to the theme of my neighbourhood. The sub-theme for the environment where I live is expected to foster the entrepreneurial mentality of students. So that students have broad insights and interesting experiences about the types of economic activities. This learning is a learning innovation that provides direct experience to students regarding entrepreneurial mentality in learning and will be attractive to students. Because, it is rare that entrepreneurship education is presented in classroom learning with an appropriate learning theme. The role-playing method helps students to have extensive knowledge and creative thinking in playing the role of a successful entrepreneur.

The Importance of Early Entrepreneurial Learning to Inculcate Entrepreneurial Mentalism is not only important for adults, but also needs to be shared as early as possible with adolescents and children to become elements of their world. The main difference in the goal is that adults use this knowledge as a proposition to increase their economic level and make money directly whereas the benefit for children is more on learning and arranging their personalities on a line outside of the normal lessons taught by teachers, parents or children. Additional tutors through training (Jamaludin et al. 2020).

Awareness of entrepreneurship from an early age apart from providing opportunities for children to be creative, they will also be happy if they are supported and have access and open space to hone their creativity. From an early age, children are educated to be more productive and less consumptive. With family support, it will show a solid view for children who are growing in love in introducing that entrepreneurial work is one of the principles so that children become independent later (At-Thariq et al. 2018).

Children at the age of elementary school (7-11 years) are at the concrete operation stage. The preoperational stage is the second stage in Piaget's theory. The concrete operational stage is the third stage in Piaget's theory. The period lasts around the age of 7 to 11 years, and is characterized by the development of organized and rational thinking (Piaget 1964). Piaget considered the concrete stage as the main turning point in the cognitive development of the child, because it marked the beginning of logical thinking. At this stage, student is mature enough to use logical thinking or thinking, but can only apply logic to physical objects. Children begin to show conservation abilities (number, area, volume, orientation). Although children can solve problems in a logical way, they are not yet able to think abstractly or hypothetically. Therefore researchers will take this age range.

The purpose of this study was to determine the application of the roleplaying method as well as supporting and inhibiting factors in fostering the entrepreneurial mentality of students in the "Theme of My Living Area" The subtheme of "My Living Environment" in 2013 curriculum Class IV at MI Muhammadiyah 2 Kudus Special Program. 


\section{LITERATURE REVIEW}

\section{Role-Playing Method}

The educational method is a method used to implement plans that have been prepared in the form of real and practical activities to achieve learning objectives. There are several learning methods that can be used to implement learning strategies, including: role playing, lectures, demonstrations, discussions, symposia, and so on. In the 2013 curriculum, student-centered learning means that in the choice of learning methods students must be actively involved in the process of seeking knowledge in skilled ways through observing, asking questions, gathering information/trying, reasoning/associating, and communicating the knowledge obtained with attitudes (Mulyono 2012).

Role-playing method is a way of mastery of learning materials through developing the imagination and appreciation of students. The development of imagination and appreciation is carried out by students by playing them as living or inanimate objects. This game is typically played by multiple people, depending on the type of game being played (Hamdayama 2015). The teacher motivates students and divides certain roles according to the script and the learning objectives to be achieved (Saefuddin and Berdiati 2014).

Learning experiences obtained from this method include: the ability to cooperate, be communicative, and interpret an event. Through the role-playing method, students try to explore the relationships between humans by demonstrating and discussing them, so that together students can explore feelings, attitudes, values, and various problem solving strategies. Role-playing methods are rooted in the personal and social dimensions. The use of the role-playing method has several objectives, including: training, motivating and cultivating courage, establishing creativity, expressing opinions, respect other students, assess the abilities of other students, explore social problems, and present alternative solutions (Setiani and Priansa 2015).

Role-playing explores human relationships by demonstrating and discussing them so that students can jointly explore feelings, attitudes, values, and various problem-solving strategies (Craciun 2005). Early childhood education is often faced with various problems, either through the field of development or through social relationships (Armstrong 2003). The role playing method is a planned learning activity designed to achieve specific educational goals (Zaini et al. 2002). Role Play is based on three main aspects of role experience in everyday life: a) Role-taking; b) Role-making; c) Role-negotiation (Howes and Cruz 2009).

The advantages of the role playing method: 1) Students are more interested in their attention to the lesson; 2) Because they play their own role, the social problem is easy to understand; 3 ) for students by playing the role of another person, they can position themselves as other people's character. The weakness is that if the teacher does not master the instructional objectives of using this technique for a unit of study, the role will not be successful (Burenkova et al. 2015).

In human relations, always pay attention to social norms, customs, habits and one's beliefs should not be abandoned so as not to offend someone. If the teacher does not understand the steps of implementing this method, it will interfere with the ongoing role play (Delnavaz et al. 2018). 


\section{Entrepreneurship Mentality}

Entrepreneurship is the ability to create something new and different. This definition implies that an entrepreneur is a person who has the ability to create something new, different from others, or able to create something different from what already existed. Entrepreneurship is defined as the process of utilizing creativity and innovation in order to solve problems and identify opportunities to improve life (business). Entrepreneurship is a creative endeavor that builds a value from what doesn't exist yet and can be enjoyed by many people (HM. 2017).

People who dare to take risks to open a business on various occasions are called entrepreneurs (Febriandika et al. 2020). Daring to take risks means being mentally independent and having the courage to start a business, without being overwhelmed by fear or anxiety even in uncertain conditions. Entrepreneurial activities can be carried out individually or in groups. An entrepreneur in his mind always tries to find, take advantage of, and create business opportunities that can provide benefits. The risk of loss is common because they hold the principle that there must be a loss factor (Febriandika et al. 2020).

An entrepreneur must have creative and innovative abilities in finding and creating various ideas. Every entrepreneurial thought and move is a business. Even the dream of a businessman is an idea to be creative in finding and creating new businesses (Kasmir 2012).

An entrepreneur must have a brave mental attitude but careful calculations will greatly help his success. So far, school education is still very minimal and has forgotten the aspects of mental development. Mental aspects fostering, for example enforcing discipline, practicing honesty in exams, completing assignments, being responsible, being brave because of being right, being afraid of being wrong, these have not been noticed.

Entrepreneurship consists of 3 main parts that cannot be separated from one another, namely: 1) entrepreneurial mental attitude, 2) entrepreneurial mental alertness, 3) entrepreneurial mental skills and skills (Alma 2014). This 3rd part has been obtained a lot from the education of existing schools. However, parts 1 and 2 still need a lot of time and thought to develop.

The Importance of Early Entrepreneurial Learning to Inculcate Entrepreneurial Mentalism is not only important for adults, but also needs to be shared as early as possible with adolescents and children to become elements of their world. The main difference in the goal is that adults use this knowledge as a proposition to increase their economic level and make money directly whereas the benefit for children is more on learning and arranging their personalities on a line outside of the normal lessons taught by teachers, parents or children, additional tutors through training (Jamaludin et al. 2020).

Awareness of entrepreneurship from an early age apart from providing opportunities for children to be creative, they will also be happy if they are supported and have access and open space to hone their creativity. From an early age, children are educated to be more productive and less consumptive. With family support, it will show a solid view for children who are growing in love in introducing that entrepreneurial work is one of the principles so that children become independent later (At-Thariq et al. 2018). 


\section{Thematic Learning}

In the 2013 curriculum, thematic learning activities in elementary schools for grades I to grade VI are carried out using integrated thematic learning. Whereas in the 2006 Curriculum (KTSP) integrated thematic learning is carried out in class I to class III. Integrated thematic learning is learning that is packaged in the form of themes based on the content of several subjects that are combined or integrated. A theme is a container or a vehicle for introducing various material concepts to students as a whole. Thematic is given with the intention of unifying curriculum content in units or units that are intact so that it contains learning that is full of value, meaningful, and easy to understand by students (Winardi 2003).

Thematic learning is an integrated learning model that uses themes to link several subjects so that they can provide meaningful experiences for students. Integrated learning is defined as learning that connects various ideas, concepts, skills, attitudes, and values between subjects and in one subject. Thematic learning places an emphasis on the selection of a specific theme that corresponds to the subject matter in order to teach one or more concepts that integrate disparate pieces of information (Malawati and Kadarwati 2017).

The characteristics of thematic learning in the 2013 curriculum are as follows: 1) centered on students, 2) providing direct experience, 3) separation of subjects is not very clear, 4) presenting concepts from various subjects, 5) being flexible, 6) learning outcomes according to the interests and needs of students, 7) using the principle of learning while playing and having fun.

One source of learning in according above criteria is the development of teaching textbooks thematic based on character education. Teaching textbooks had a role as a supplement or supporting books for learners to learn independently without assistance teachers. In addition, teaching textbooks used as appendages source of learning students to book teachers and students book existing (Wuryani 2018). The development of textbooks chosen was based on learning thematic character education which rests on the theory contextual. In theory, contextual learning will meaningful when associated with daily life. Teaching textbooks will be made possible by showing illustration in daily events containing the character education. In addition, in every thetheme lessons also would be related to elements character education. So that there will be reciprocal between learning thematic with character education. In general, this method tends to have a better level of learning effectiveness than conventional learning methods (Huang et al. 2007; Wuryani 2018; Mudiono et al. 2016).

\section{Children Learning Development Stage}

Piaget (1964) divides the development of children's thinking into the following stages: 0-2 years of age (sensorimotor), 2-7 years (preoperational), 7-11 years (concrete operations) and 11 years of age (formal operation). Each stage shows unique, dynamic and psychological characteristics of learning behavior in that age range. Children at the age of elementary school (7-11 years) are at the concrete operation stage. The preoperational stage is the second stage in Piaget's theory. The concrete operational stage is the third stage in Piaget's theory. The period lasts around the age of 7 to 11 years, and is characterized by the development of organized and rational thinking (Piaget 1964). Piaget considered the concrete stage as the main turning point in the cognitive development of the 
child, because it marked the beginning of logical thinking. At this stage, student is mature enough to use logical thinking or thinking, but can only apply logic to physical objects. Children begin to show conservation abilities (number, area, volume, orientation). Although children can solve problems in a logical way, they are not yet able to think abstractly or hypothetically. Therefore researchers will take this age range.

In this age range, concrete children's behavior, namely: (1) Students begin to view the world objectively, shift from one aspect of the situation to another aspect reflectively and see the elements simultaneously. (2) Students begin to think operationally. (3) Students are able to use operational thinking to clarify objects. (4) Learners can form and use connectedness rules, simple scientific principles and use causal relationships. (5) Students can understand the concepts of substance, length, width, breadth, height, low, light and weight.

The learning tendency of elementary school age children has three characteristics, namely: concrete, integrative, and hierarchical (Rusman 2015): (1) Concrete means that the learning process starts from concrete things, namely those that can be seen, heard, smelled, touched, manipulated. Utilization of the environment will produce a meaningful and valuable learning process, because students are faced with actual events and circumstances. (2) Integrative, namely seeing something that is learned as a whole and integrated. Elementary school age children have not been able to sort the concepts from various disciplines. (3) Hierarchical, namely developing in stages starting from simple things to things that are more complex.

\section{METHODS}

This research is a field research that uses a qualitative research approach. This research was carried out at MI Muhammadiyah 2 Kudus Special Program which is addressed in the village of Damaran, Kudus city. The reason for choosing this location is because this madrasah is one of the Madrasah Ibtidaiyah in Kudus which applies the role-playing method in fostering the entrepreneurial mentality of its students as a breakthrough to make MI Muhammadiyah 2 Kudus a special program to become a superior madrasah. The subjects in this study were 1 class teacher, 1 headmaster and 20 grade IV students at MI Muhammadiyah 2 Kudus Special Program. According to Arikunto (2012), if the population is less than 100 people, then the number of samples taken as a whole, but if the population is greater than 100 people, it can be taken $10-15 \%$ or $20-25 \%$ of the total population. Based on this research, because the total population is not greater than 100 respondents, the authors take $100 \%$ of the total population of grade 4 students.

Data sources used are primary and secondary data through observation, interviews, and documentation. In secondary data sources, researchers get through the literature, namely books that have relevance to the research conducted. In addition, secondary data also comes from RPP (the theme of the area where I live, the sub-theme of the environment where I live in learning four), role playing scripts, organizational structure, vision and mission of the MI Muhammadiyah 2 Kudus Special Program, learning process schedules, data on educators who teach and student data at MI Muhammadiyah 2 Kudus Special Program. In data 
collection techniques, triangulation is defined as a data collection technique that combines various data collection techniques and existing sources (Afifuddin and Saebani 2009). When the researcher collects data by triangulation, the researcher actually collects data which also tests the credibility of the data, namely checking the credibility of the data with various data collection techniques and various data sources (Putra 2013).

Analysis techniques in qualitative research in the form of suggestions from material expert validators were carried out descriptively qualitatively. Activities in data analysis are data reduction, where at this stage the researcher chooses and focuses attention for simplification and transformation of the crude data obtained, data display (data presentation), namely the researcher develops a description of structured information to draw conclusions and take action, and conclusion drawing/verification, namely the researcher tries to draw conclusions and carry out verification by looking for the meaning of each symptom obtained in the field (Azwar 1998).

\section{RESULTS AND DISCUSSION}

\section{Implementation of Role-Playing Method}

Thematic learning at MI Muhammadiyah 2 Kudus started in 2017/2018 but not yet comprehensive in all classes, only grades 1, 2, 3, and 4 have implemented thematic learning. In the 2018/2019 academic year all classes have used thematic learning according to government regulations (Mariatun and Indriani 2018). In the thematic learning process, students are more focused on as the main subject in learning (Malawati and Kadarwati 2017). Teachers have more role as facilitators and motivators in the learning process. Thematic learning emphasizes learning by providing direct experience to students. So that what students learn in class can be practiced in everyday life (Malawati and Kadarwati 2017).

Role-playing method is good when applied in learning. However, not all themes can use this method. The role-playing method is a learning method that provides experience for students to play other people's characters (Saefuddin and Berdiati 2014). As in the theme of the area where I live, the sub-theme of the environment where I live is one of the themes that can use the role-playing method to foster the entrepreneurial mentality of students (Mariatun and Indriani 2018). There are students who play roles as producers, consumers, and distributors.

In choosing and determining a theme, there are several things that need to be considered, including: a) the chosen theme must allow higher order thinking processes to occur in students and related to their learning methods and habits, b) The scope of the theme is adjusted to the age and development of students, including interests, needs and abilities and c) Determination of themes starting from the environment closest to and recognized by students. In the 2013 curriculum, the themes have been determined by the ministry of education and culture (Mariatun and Indriani 2018).

The scope of the theme set should not be too broad or too narrow. A theme that is too broad can be translated into sub-themes that are more specific and more concrete in nature. The sub-theme can then be further developed into several 
learning activities. In the 2013 curriculum, each sub-theme consists of six (6) learning activities. For example, for grade IV, the theme of "My Living Area" can be developed into sub-themes: (1) the environment where I live, (2) the uniqueness of the area where I live, and (3) proud of the area where I live. The fourth grade themes that have been established by the ministry of education and culture in the 2013 curriculum are as follows: (1) The beauty of togetherness, (2) Always save energy, (3) Care for living things, (4) Various jobs, (5) My heroes, (6) The beauty of my country, (7) My dreams, (8) The area where I live, (9) My food is healthy and nutritious.

As has been implemented by grade IV teachers at MI Muhammadiyah 2 Kudus, a special program that uses the role-playing method and chooses the theme of the area where I live, the sub-theme of the environment where I live, learning four (4) in fostering the entrepreneurial mentality of students. In the theme of the area where I live, the sub-theme of the environment where I live, learning four (4) there are several competencies that can be achieved from role playing activities, including: PPKN; Indonesian language; and Social Sciences. This theme was chosen as the only grade 4 materials that could be used to develop students' entrepreneurial mentality. Other themes are not related to entrepreneurial mental development.

As an educator, there are several stages in implementing the role-playing method at MI Muhammadiyah 2 Kudus, including: (1) Planning steps. Teachers carefully study the activity to be role-played and note the parts or steps that will be demonstrated. They make a role play scenario referring to the topic and learning objectives and notes about the main sections and steps that were made in the previous step (Delnavaz et al. 2018). These scenarios include: flow and procedure of simulated activities, various roles, characters and actors; the main keys of the procedures and competencies to be taught along with the standards of success; prepare and check other supporting equipment and equipment. Conducting trials and refining the simulation scenario that has been developed into the final scenario to be used in class. (2) Preparatory steps. Teachers prepare and check the readiness of equipment and other supporting equipment (Delnavaz et al. 2018). They explain to students a general picture of playing roles and their relation to the topic being studied, the goals to be achieved and what is expected of the students. Then they prepare an enhanced role-playing scenario. They distribute activity scripts to students according to their respective roles and provide explanations of what they should and what they shouldn't do. They give students the opportunity to ask questions to clarify their understanding of role playing activities. (3) Implementation steps. Students are directed to carry out step by step role-playing activities according to the scenario (Delnavaz et al. 2018). The teacher acts as a director who controls so that role playing activities go according to the scenario and are carried out seriously. The teacher reminds students who are not serious enough to focus on activities in order to give meaning to themselves and the class. The teacher makes notes about things that need to be discussed at the end of the lesson which includes things that need to be praised and things that need to be improved. If time is still available, repeat the steps step by step by first discussing what needs to be improved. If necessary, make a role rotation among fellow students to increase the extent of mastery of competencies and also increase the enthusiasm for learning of students. Teacher 
Ask students to name a step-by-step sequence at sub-normal speed and the teacher takes steps according to the sequence mentioned by the student. (4) Evaluation and closing steps. The teacher asks a question related to the part or step that was just demonstrated based on the notes that have been made (Delnavaz et al. 2018). They ask them for comments from students about the implementation of the steps taken by their friends. The teacher creates a summary of role-playing activities related to the learning objectives by extracting them from the students.

In addition, in the process of applying the role-playing method there are several important points held by the teacher which are in accordance with the study of Setiani and Priansa (2015). so that activities run optimally, namely: (1) warming the atmosphere and motivating students, (2) selecting participants / roles, (3) arranging role stages, (4) preparing observers, (5) acting, (6) discussion and evaluation, (7) re-enactment, (8) discussion and evaluation phase two, (9) sharing experiences and drawing conclusions.

\section{The Output of Role-Playing Method}

Creating an attractive learning atmosphere for students requires teachers to be creative in delivering material to students with a certain method at MI Muhammadiyah 2 Kudus. One method that is attractive to students is the roleplaying method. The role-playing method invites students to be actively involved in playing a role as if they are playing a role like the original character. The roleplaying method is expected not only to provide the concept of the material but, students are able to apply the material obtained and then applied in everyday life (Setiani and Priansa 2015).

Instilling an entrepreneurial mentality must be done as early as possible. Because, the cultivation of an entrepreneurial mentality requires a process that is not short-lived, so the cultivation starts early so that when they mature, the mentality will grow solidly in students. So that students are able to prepare for a better future to become entrepreneurs.

\section{Figure 1 Output Role-Playing Method}

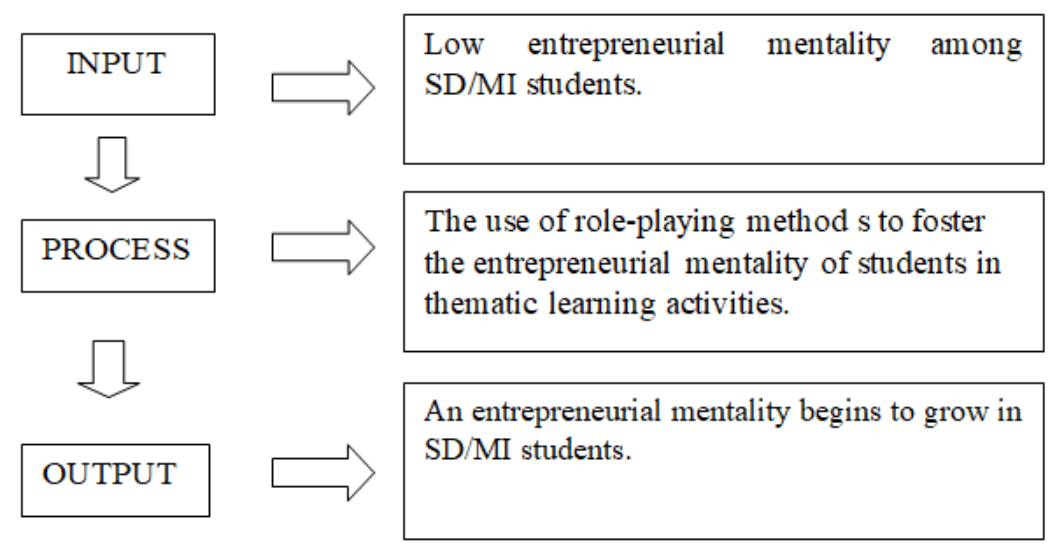

Source: data processed

The application of the role-playing method to the theme of the area where I live, the sub-theme of the environment where I live, is expected to be able to shape students to have an entrepreneurial mentality (Zaini et al. 2002). Students 
will remember a material more if the material is delivered with a method that provides direct experience to students and the role-playing method can provide opportunities for students to play roles as if students are doing activities like the original character (Rusman 2015; Piaget 1964). The entrepreneurial mentality includes discipline respecting time, being brave, honest, never giving up, and so on. The relationship between role-playing methods and fostering an entrepreneurial mentality can be seen in the following Figure 1.

\section{Advantages and Disadvantages of Role-Playing Method}

Each learning method certainly has its advantages and disadvantages when applied to a particular material. The advantages and disadvantages of a role playing learning method can be minimized by each teacher. The following are the advantages of the role-playing method at MI Muhammadiyah 2 Kudus which in accordance with Burenkova et al. (2015): a) involving all students so that they can participate and have the opportunity to advance their ability to work together; b) students are free to make decisions and express themselves in their entirety; c) games are easy inventions and are used in different situations and times; d) the teacher can evaluate the understanding of each student through observation when playing games; e) the game is a fun learning experience for students.

The strengths of the role-playing method must also be collaboration between teachers and students as recommended by several studies (Huang et al. 2007; Wuryani 2018; Mudiono et al. 2016). The teacher must prepare materials to be dramatized in accordance with the mental development of the students. So that students get a learning experience while playing.

Meanwhile, the disadvantages of the role-playing method are in accordance with study of Jamaludin et al. (2020) which as follow: a) some students who do not play become less active; b) time consuming; c) requires a large space; d) often other classes are annoyed by the sound of the performers and the applause of the audience / observer .

Weaknesses in the role-playing method can be minimized by the teacher if the teacher is able to plan effectively and efficiently. For example, the roleplaying method takes a long time. So it can be minimized by limiting the time that has been mutually agreed upon. So that teachers and students can perform role playing in a short time but, there are lessons to be learned.

\section{Supporting and Inhibiting Factors of Role-Playing Method}

Based on research conducted at MI Muhammadiyah 2 Kudus Special Program, there are several factors that support the success of thematic learning using the role-playing method in fostering the entrepreneurial mentality of students, including: (1) Teacher ability, teachers have an important role in the learning process. Teachers should have the ability to display subject matter by applying effective learning methods. When the teacher wants to use the role palying method in teaching and learning activities, the teacher must be able and ready to apply it in learning. The teacher is said to be capable if the teacher can understand the steps in the role-playing method in fostering the entrepreneurial mentality of students. (2) Readiness of students, thematic learning centered on students. Students become the main object in learning. When applying a learning method, students must be in a state of being ready to accept the subject matter that 
the teacher will deliver. (3) Suitable theme, each class has a theme and not all themes can use the role-playing method in fostering the entrepreneurial mentality of students. The theme of the area where I live, the sub-theme of the environment where I live, can use the role-playing method in fostering the entrepreneurial mentality of students. A suitable theme can be one of the supporting factors for the use of the role-playing method in fostering the entrepreneurial mentality of students in thematic learning. (4) Role playing tools and materials, the implementation of the role-playing method requires tools and materials to support role playing in order to foster the entrepreneurial mentality of students. In the theme of the area where I live, the sub-theme of the environment where I live, learning 4 contains material on economic activities. Students play a role in accordance with the scenario created by the teacher and in order for the role play to be good it must be supported by tools and materials according to what role is played.

Based on research conducted at MI Muhammadiyah 2 Kudus Special Program, there are several factors that can hinder the implementation of the roleplaying method in fostering the entrepreneurial mentality of students in thematic learning (the theme of the area where I live, the sub-theme of the environment where I live), including: (1) Lack of students' courage (Setiani and Priansa 2015). Students have a variety of different characters. So when choosing the role of the teacher must adjust the character possessed by students. When playing roles, there are students who are brave and there are also those who are embarrassed in playing that role and it can also hinder the application of the role-playing method in fostering the entrepreneurial mentality of students. (2) It takes a lot of time (Huang et al. 2007; Wuryani 2018; Mudiono et al. 2016). (3) The allocation of thematic learning time, namely 1 day, must complete learning in that theme. When using the role-playing method, it certainly takes a lot of time compared to using the lecture, discussion, question and answer method, etc. The role-playing method requires a lot of preparation, depending on the time of implementation it depends on the students who play it (Setiani and Priansa 2015; Mudiono et al. 2016). If students can be invited to work together to play the role well, the roleplaying method can be completed according to a predetermined time. The amount of time involved in role playing can also be overcome by creating an agreed time frame.

\section{CONCLUSION}

Thematic learning at MI Muhammadiyah 2 Kudus Special Program according to researchers is already good in accordance with the steps in the 2013 curriculum. The teacher tries to present thematic learning with interesting methods and the material presented can be useful for the daily life of students. The application of the role-playing method in fostering the entrepreneurial mentality of students on the theme of the area where I live, the sub-theme of the environment where I live in grade IV at MI Muhammadiyah 2 Kudus Special Program according to researchers is very effective. This is evidenced when learning using the role-playing method students becomes more active in learning.

There are three stages in the learning process, namely planning, implementation, and evaluation. Before learning activities, the teacher makes 
planning for the implementation of learning which is then realized in the implementation of learning in which there is a learning process, namely, introduction, core activities, and closing. The preliminary process of the teacher provides perceptions, motivation, and learning objectives to be conveyed. In the core activity, the teacher explains briefly the material on the types of economic activities and applies the learning method as planned, namely the role-playing method. Students are invited to play while learning, namely to play the role of types of economic activities. There are three types of economic activity, namely producers, consumers, and distributors. Students are given roles by existing abilities that students have or agree on. Some play a role as buyers, juice sellers, fruit farmers, barbers, bookstore owners, employees. After the role-play is complete, the teacher and students evaluate the learning. The entrepreneurial mentality of students begins to grow and they are eager to learn from an early age to become successful entrepreneurs so that children can learn independently from childhood. Entrepreneurship education can also be applied in thematic learning.

Supporting factors for the application of the role-playing method in fostering the entrepreneurial mentality of students in learning the theme of the area where I live, the sub-theme of the environment where I live at MI Muhammadiyah 2 Kudus Special Program, there are four factors, namely: the ability of the teacher to manage the classroom using the role-playing method, the readiness of students. In the learning process, including preparing equipment and learning resources, suitable themes, namely the theme of the area where I live, the sub-theme of the environment where I live, and the tools and materials in playing roles. While the inhibiting factors are twofold, namely: the lack of courage of students in interacting with interlocutors because they are embarrassed and require a lot of time in playing roles so that teachers must be able to manage learning time properly so that learning objectives using role-playing can be achieved. Therefore, educators are expected to be able to supervise students in carrying out roleplaying activities so that students can experience and apply for the benefits in the future.

\section{REFERENCES}

Afifuddin, Beni Ahmad Saebani, and Beni Ahmad Saebani. 2009. Metodologi Penelitian Kualitatif. Bandung: Pustaka Setia.

Alma, Buchari. 2014. Kewirausahaan. Bandung: Alfabeta.

Arikunto, Suharsimi. 2012. Penelitian tindakan kelas. Jakarta: Bumi Aksara.

Armstrong, E. Kate. 2003. "Applications of Role-Playing in Tourism Management Teaching: an Evaluation of a Learning Method." Journal of Hospitality, Leisure, Sport and Tourism Education 2(1), 5-16. https://doi.org/10.3794/johlste.21.24.

At-Thariq, M. Rizal, R.M Sugandi, and Priyono Priyono. 2018. "Hubungan Lingkungan Keluarga, Lingkungan Sekolah, Dan Lingkungan Masyarakat Terhadap Minat Berwirausaha Siswa Kelas XI SMK Negeri 3 Boyolangu." Jurnal Bangunan 23(2), 35-46. http://journal2.um.ac.id/index.php/bangunan/article/view/5576.

Azwar, Saifuddin. 1998. Metode Penelitian. Yogyakarta: Pustaka Pelajar Offset. 
Burenkova, Olga Mikhailovna, Irina Vladimirovna Arkhipova, Sergei Aleksandrovich Semenov, and Saniya Zakirzyanovna Samarenkina. 2015. "Motivation within Role-Playing as a Means to Intensify College Students' Educational Activity." International Education Studies 8(6), 211-216. https://eric.ed.gov/?id=EJ1067803.

Bystrova, Natalia V., Elena A. Konyaeva, Julia M. Tsarapkina, Irina M. Morozova, and Anna S. Krivonogova. 2017. "Didactic Foundations of Designing the Process of Training in Professional Educational Institutions." International conference on Humans as an Object of Study by Modern Science: The Impact of Information on Modern Humans 136142. https://doi.org/10.1007/978-3-319-75383-6_18.

Craciun, Dana. 2010. "Role-Playing as a Creative Method in Science Education." Journal of Science and Arts Year 10 1(12), 175-182. http://www.josa.ro/docs/josa_2010_1/c.11_role_playing_as_a_creative_m ethod_in_science_education.pdf.

Delnavaz, Samira, Hadi Hassankhani, Fariborz Roshangar, Dadashzadeh, Abbas Dadashzadeh, Parvin Sarbakhsh, Mansour Ghafourifard, and Eskandar Fathiazar. (2018). "Comparison of Scenario Based Triage Education By Lecture and Role Playing on Knowledge and Practice of Nursing Students." Nurse Education Today 70, 54-59. https://doi.org/10.1016/j.nedt.2018.08.006.

Erbil, Deniz Gökçe, and Ayfer Kocabaş. 2018. "Cooperative Learning as a Democratic Learning Method." Journal of Research in Childhood Education 32(1), 81-93. https://doi.org/10.1080/02568543.2017.1385548.

Febriandika, Nur Rizqi, Afifah Nur Millatina, Luthfiyatillah Luthfiyatillah, and Sri Herianingrum. 2020. "Customer E-Loyalty of Muslim Millennials in Indonesia: Integrated Model of Trust, User Experience and Branding in ECommerce Webstore." IC4E 2020: Proceedings of the 2020 11th International Conference on E-Education, E-Business, E-Management, and E-Learning, 369-376. https://doi.org/10.1145/3377571.3377638.

Fedosejeva, Jelena, Aleksandrs Boce, Marija Romanova, Dzintra Ilisko, and Oksana Ivanova. 2018. "Education for Sustainable Development: The Choice of Pedagogical Approaches and Methods for the Implementation of Pedagogical Tasks in the Anthropocene Age." Journal of Teacher Education for Sustainability 20(1), 157-179. https://eric.ed.gov/?id=EJ1218216.

Guerrero, Antonio José Moreno, Carmen Rodríguez Jiménez, Gerardo Gómez García, and Magdalena Ramos Navas Parejo. 2020. "Educational Innovation in Higher Education: Use of Role Playing and Educational Video in Future Teachers' Training." Sustainability 12(6), 2558. https://doi.org/10.3390/su12062558.

Hamdayama, Jumanta. 2015. Model dan Metode Pembelajaran Kreatif dan Berkarakter. Bogor: Penerbit Ghalia Indonesia.

HM., Muhammad Anwar. 2017. Pengantar Kewirausahaan. Jakarta: PT. Kharisma Putra Utama.

Howes, Elaine V., and Bárbara C. Cruz. 2009. "Role-Playing in Science Education: An Effective Strategy For Developing Multiple 
Perspectives." Journal of Elementary Science Education 21, 33-46. https://doi.org/10.1007/BF03174721.

Huang, Chenn-Jung, Ming-Chou Liu, San-Shine Chu, and Chih-Lun Cheng. 2007.

"An Intelligent Learning Diagnosis System for Web-Based Thematic Learning Platform." Computers \& Education 48(4), 658-679. https://doi.org/10.1016/j.compedu.2005.04.016.

Jamaludin, Jamaludin, Sirajuddin Sirajuddin, Thamrin Thamrin, Masran Mustakim, and Jakariah Jakariah. 2020. "Menumbuhkembangkan Jiwa Kewirausahaan Siswa Di Pondok Pesantren Al-Manar Cibeuteung Udik, Kecamatan Ciseeng, Kabupaten Bogor. Lokabmas: Jurnal Loyalitas Kreatifitas Abdi Masyarakat $\quad$ Kreatif 1(2), 62-72. http://dx.doi.org/10.32493/jlkklkk.v1i2.p62-72.6376.

Kasmir, Kasmir. 2012. Kewirausahaan. Jakarta: Raja Grafindo Persada.

Luo, Yu Jy. 2019. "The Influence of Problem-Based Learning on Learning Effectiveness in Students' of Varying Learning Abilities Within Physical Education." Innovations in Education and Teaching International 56(1), 313. https://doi.org/10.1080/14703297.2017.1389288.

Malawati, Ibadullah, and Ani Kadarwati. 2017. Pembelajaran Tematik (Konsep dan Aplikasi). Magetan: CV. AE Media Grafika.

Mariatun, Ika Lis, and Dian Eka Indriani. 2018. "Penguatan Pendidikan Karakter Berbasis Pancasila melalui Kurikulum K13 di Sekolah Dasar." CivicCulture: Jurnal Ilmu Pendidikan PKN dan Sosial Budaya 2(2), 153-160. http://publikasi.stkippgri-bkl.ac.id/index.php/CC/article/view/79.

Mudiono, Alif, Muhana Gipayana, and Suhel Madyono. 2016. "Developing of Integrated Thematic Learning Model Through Scientific Approaching With Discovery Learning Technique in Elementary School”. International Academic Journal of Social Sciences 3(2), 159-167. https://www.iaiest.com/datacms/articles/20191010023929pmIAJSS1510037.pdf.

Mulyono, Mulyono. 2012. Strategi Pembelajaran: Menuju Efektivitas Pembelajaran di Abad Global. Malang: UIN-Maliki Press.

Nurdin, Tati Arifah, M. Japar, Ishak G. Bachtiar, and Adi Apriadi Adiansha. 2018. "Improving Social Attitudes and Knowledge Through Role-Playing Method." American Journal of Educational Research 6(7), 1040-1045. https://doi.org/10.12691/education-6-7-23.

Piaget, Jean. 1964. "Cognitive Development in Children: Piaget". Journal of Research In Science Teaching 2(3), 176-186.

Pujiati, Desti. 2015. "Peningkatan Keterampilan Sosial Melalui Metode Bermain Peran”. Dinamika: Jurnal Ilmiah Pendidikan Dasar,7(1). http://www.jurnalnasional.ump.ac.id/index.php/Dinamika/article/view/919

Putra, Nusa. 2013. Metode Penelitian Kualitatif Pendidikan. Jakarta: PT Raja Grafindo.

Rusman, Rusman. 2015. Pemelajaran Tematik Terpadu Teori, Praktik dan penilaian. Depok: PT Raja Grafindo Perkasa.

Saefuddin, Asis, and Ika Berdiati. 2014. Pembelajaran Efektif. Bandung: PT. Remaja Rosdakarya.

Setiani, Ani, and Donni Juni Priansa. 2015. Manajemen Peserta Didik dan Model Pembelajaran: Cerdas, Kreatif, dan Inovatif. Bandung: Alfabeta. 
Wijayanti, Nira Arum. 2017. "Implementation of Role-playing method in the Hygiene Hadith Learning Toward Early Children's Healthy Behavior of Group B in Dabin Aggrek Gunungpati Semarang." BELIA: Early Childhood Education Papers 6(2), 126-130. https://journal.unnes.ac.id/sju/index.php/belia/article/view/20783.

Winardi, Winardi. 2003. Entrepreneur \& Entrepreneurship. Jakarta Timur: Prenada Media.

Wuryani, Meilan Tri, Roemintoyo Roemintoyo, and Sri Yamtinah. 2018. "Textbooks Thematic Based Character Education on Thematic Learning Primary School: an Influence." International Journal of Educational Methodology 4(2), 75-81. https://eric.ed.gov/?id=EJ1180055.

$\mathrm{Xu}$, Duoduo. 2018. "From Poverty to Prosperity: College Education, Noncognitive Abilities, and First-Job Earnings." Chinese Sociological Review 50(1), 53-82. https://doi.org/10.1080/21620555.2017.1376581.

Zaini, Hisyam, Bermawy Munthe, and Sekar Ayu Aryani. 2002. Strategi Pembelajaran Aktif Di Perguruan Tinggi. Yogyakarta: Center for Teaching Staff Development. 